\title{
ANALISIS CITRA MEREK, KUALITAS PRODUK, DAN BAURAN PROMOSI EFEKNYA TERHADAP KEPUTUSAN PEMBELIAN PASTA GIGI PEPSODENT (STUDI KASUS DI PERUMAHAN CILEDUG INDAH 2 PERIODE MARET - MEI 2015)
}

\author{
Priscilla Loekman \\ Program Studi Magister Manajemen Universitas Tarumanagara \\ priscilla.loekman@gmail.com \\ Chairy \\ Program Studi Magister Manajemen Universitas Tarumanagara
}

Masuk : 20-11-2017, revisi : 06-12-2017 diterima untuk diterbitkan : 06-12-2017

\begin{abstract}
Increased business development in toothpaste, all businesses strive to attract customers and retain customers in various ways. Pepsodent toothpaste always strive to provide brand image such as quality superior to other brands. Pepsodent toothpaste has a quality product that organizes dental health events and optimizes the promotion mix always informs new products. The purpose of this research is analysis of brand image analysis, product quality, and promotion mix of its effect to purchase decision of Pepsodent toothpaste. In this research is done by literature study, observation, interview, and spreading of questionnaire. This population is the competitor users of Pepsodent Toothpaste in Ciledug Indah Estate 2. The sample used is 67 people and selected using Probability Sampling, precisely using simple random sampling. Simple correlation analysis tool to know the relationship between variables. Multiple linear regression analysis is useful to know the effect of dependent variable. Variables of brand image and quality partially have a significant influence on the public interest using Pepsodent toothpaste. The promotional mix variable partially has no significant effect on the public interest using Pepsodent toothpaste. The regression equation formed is $\mathrm{Y}=3.548+0.26$ $(\mathrm{X} 1)+0.497(\mathrm{X} 2)$. Brand image variable (X1) has a positive effect on purchasing decisions. Product quality variables (X2) also have a positive effect on purchasing decisions. Brand image variables and product quality simultaneously have a significant influence on the public interest using Pepsodent toothpaste.
\end{abstract}

Keywords : Citra Merek, Kualitas Produk, Bauran Promosi

\section{PENDAHULUAN}

Pada hakekatnya konsumen merupakan faktor penting bagi berlangsungnya hidup perusahaan, sekarang ini konsumen sudah pintar dan cermat dalam mencari sebuah informasi atas produk maupun jasa, yang nantinya bisa bermanfaat memenuhi keinginan dan bisa memuaskannya (Grunert, 2015). Persaingan yang begitu ketat dewasa ini menuntut perusahaan-perusahaan agar mampu memainkan strategi pemasaran yang handal dan mampu menarik minta konsumen sehingga dapat memenangkan pasar (Jain \& Haley, 2009). Perusahaan sudah semestinya lebih terfokus pada konsumen agar dapat memenangkan persaingan. Dengan memberikan kepuasan pada konsumen maka akan dapat membangun kepercayaan konsumen dan akhirnya tercipta hubungan yang erat antara konsumen dan perusahaan. Menurut Kotler dan Keller (2009) konsep pemasaran, perusahaan yang bisa bertahan dan memenangkan persaingan dipasar global adalah perusahaan yang mampu menawarkan nilai lebih dan sesuai dengan keinginan pelanggan (Rust, Lemon, \& Zeithaml, 2004).

Oleh karena itu untuk mencapai kesuksesan perusahaan memenuhi syarat yang dipenuhi agar dapat mencapai sukses dalam persaingan. Misalnya seperti mencapai tujuan untuk 
menciptakan dan mempertahankan pelanggan. Agar tujuan tersebut tercapai, maka setiap perusahaan berupaya menghasilkan dan menyampaikan barang dan jasa yang diinginkan konsumen dengan harga yang sesuai (Cravens \& Piercy, 2006). Dengan demikian, setiap perusahaan mampu memahami perilaku konsumen sangat tergantung pada perilaku konsumennya (Tjiptono \& Chandra, 2011). Perilaku konsumen diketahui perusahaan sebagai strategi dalam menarik pasar. Strategi pemasaran merupakan alat fundamental yang direncanakan untuk mencapai tujuan perusahaan dengan mengembangkan keunggulan bersaing yang berkesinambungan melalui pasar sasaran tersebut. Strategi pemasaran yang digunakan untuk melayani pasar sasaran tersebut. Strategi pemasaran memberikan arah dalam kaitannya dengan variabel-variabel seperti segmentasi pasar, identifikasi pasar sasaran, positioning, elemen bauran pemasaran dan biaya bauran pemasaran (Tjiptono \& Chandra, 2012). Masyarakat sudah lebih sadar dan peduli akan kesehatan dan kebersihan pada giginya, karena itu bisa membuat orang tersebut bisa lebih percaya diri untuk berkomunikasi. Selain itu masyarakat juga lebih diyakini oleh kegiatan-kegiatan sosial yang dilakukan oleh perusahaanperusahaan produk pasta gigi, yang melakukan penyuluhan maupun transfer ilmu akan pentingnya kesehatan dan kebersihan gigi kepada masyarakat (Tjiptono \& Chandra, 2012).

Saat ini banyak terdapat produsen-produsen pasta gigi yang bisa didapati di pasaran seperti Pepsodent, Ciptadent, Formula, Close up, Sensodyne, Smile Up, Enzim dan Maxam. Diantara produsen pasta gigi tersebut untuk saat ini Pepsodent masih memimpin pasar, karena Pepsodent paling terdepan dalam berinovasi, produk ini seringkali menjadi awal pelopor dalam melakukan trobosan-trobosan dan pengklasifikasian dalam pasta gigi. Pepsodent tidak hanya mengeluarkan produk pasta gigi yang hanya untuk menyegarkan nafas dan memutihkan gigi saja, tetapi pepsodent juga terus berinovasi mengikuti permintaan dari apa yang dibutuhkan oleh gigi konsumen, karena masing-masing varian yang dikeluarkan oleh pasta gigi Pepsodent memiliki fungsi yang berbeda agar manfaat yang didapatkan lebih maksimal, misalnya seperti pepsodent complete age lebih tertuju untuk merawat kekuatan email dan mengurangi pembentuk aplak selama 18 jam, Pepsodent sensitive expert yang mengertiakan gigi sensitive, Pepsodent game care yang berfungsi untuk menguatkan gusi dan mengurangi gusi yang berdarah dan masih banyak varian lainnya. Selama tahun berturut-turut, pepsodent mampu mempertahankan posisinya sebagai Top Brand pada Top Brand Award. Index pasta gigi Pepsodent memang yang paling besar diantara merek pasta gigi lainnya namun index tersebut tidak stabil terutama bila melihat index Pepsodent tahun 2014 yang menurun $0,8 \%$ dari tahun 2013.

Beberapa merek yang memiliki kualitas yang relatif sama dapat memiliki kinerja yang berbeda-beda dipasar karena perbedaan persepsi yang tertancap dibenak konsumen (Völckner, et al, 2010). Oleh karena itu suatu merek yang dirancang perusahaan harus dapat memenuhi apa yang dibutuhkan dan diinginkan konsumen serta dikomunikasikan dengan baik, sehingga pada saat konsumen membutuhkan produk tertentu, maka konsumen akan memutuskan produk dengan merek tersebut yang menjadi pilihan utama untuk dibeli (Steenkamp, et al, 2003). Merek (brand) bukanlah sekedar nama, istilah (term), tanda (sign), simbol atau kombinasinya, (Allenby \& Rossi, 1991). Lebih dari itu merek adalah janji perusahaan secara konsisten memberikan features, benefits, dan services kepada para pelanggan. Dan "janji” inilah yang membuat masyarakat luas mengenal merek tersebut, lebih dari yang lain. Dari pernyataan tersebut membuktikan bahwa citra merek dapat memberikan keyakinan bagi konsumen dalam melakukan pembelian suatu produk. Karena persepsi kualitas merupakan persepsi konsumen maka dapat diramalkan jika persepsi kualitas konsumen negatif, produk tidak akan disukai dan tidak akan bertahan lama di pasar. Sebaliknya, jika persepsi kualitas pelanggan positif, produk akan disukai, dengan beranggapan bahwa kualitas produk yang baik merupakan jaminan kepuasan dalam menggunakan produk tersebut untuk memenuhi kebutuhan hidupnya (Athiyaman, 1997). Dengan persepsi kualitas yang baik akan menciptakan suatu image yang baik bagi suatu produk yang akan menimbulkan keputusan pembelian oleh konsumen. Citra 
merek adalah seperangkat keyakinan, ide, dan kesan yang dimiliki oleh seseorang terhadap suatu merek. Dari pernyataan tersebut membutikan bahwa citra merupakan image yang terbentuk dimasyarakat (konsumen/pelanggan) tentang baik buruknya perusahaan.

Selain itu dimensi dari kualitas produk juga merupakan salah satu faktor penting, karena dengan kondisi sekarang ini produk yang berkualitas mempunyai nilai lebih dibandingkan dengan produk pesaing. Kualitas merupakan totalitas fitur dan karakteristik produk atau jasa yang bergantung pada kemampuannya untuk memuaskan kebutuhan yang dinyatakan atau tersirat Kotler dan Keller (2010). Kualitas yang bagus dan terpercaya, maka produk senantiasa akan tertanam dibenak konsumen, karena konsumen bersedia membayar sejumlah uang untuk membeli produk yang berkualitas (Vigneron \& Johnson, 2017). Persepsi konsumen terhadap kualitas produk akan membentuk preferensi dan sikap pada gilirannya akan mempengaruhi keputusan untuk membeli atau tidak (Thakor \& Lavack, 2003).

Dilihat dari segi citra merek dan kualitas produk citra merek sudah tidak diragukan lagi, tetapi itu saja tidak cukup untuk menyakinkan konsumen, oleh karena itu untuk dapat mengenal produk yang diciptakan dengan segala keunggulannya tersebut pada konsumen maka perusahaan perlu menerapkan strategi promosi yang baik. Promosi adalah arus informasi satu arah yang dibuat untuk mengarahkan seseorang atau organisasi kepada tindakan yang menciptakan pertukaran atau transaksi dalam pemasaran. Dengan promosi menyebabkan orang yang sebelumnya tidak tertarik untuk membeli suatu produk atau jasa akan menjadi tertarik dan mencoba produk atau jasa sehingga konsumen melakukan pembelian (Van Doren, et al, 2000). Promosi adalah berbagai cara untuk menginformasikan, membujuk, dan mengingatkan konsumen secara langsung maupun tidak langsung tentang suatu produk atau brand yang dijual (Kotler \& Keller, 2010).

Pepsodent sangat aktif dalam mempromosikan segala produknya, salah satu contohnya pepsodent mengadakan even-even disupermarket-supermarket besar, misalnya di Carefour, Lottemart, Hypermarket, Giant. Even yang di adakan disupermarket, ini merupakan salah satu cara dari pepsodent agar konsumen yang belum pernah memakai pepsodent bisa tau dan mencobanya dengan cara sales promotion girl menjelaskan produk Knowlavge kepada konsumen dan memberikan hadiah kepada konsumen yang membelinya. Cara ini terbukti lebih efektif untuk mengajak konsumen tersebut dengan keunggulan-keunggulan dan hadiah kepada konsumen yang tadinya tidak ingin membeli pasta gigi pepsodent menjadi ingin membeli, karena secara tidak langsung sales promotion girl tersebut mendoktrin konsumen tersebut dengan keunggulan-keunggulan dan hadiah yang menarik dari pasta gigi tersebut. Pada hakikatnya promosi adalah suatu bentuk komunikasi pemasaran. Komunikasi pemasaran adalah aktivitas pemasaran yang berusaha menyebarkan informasi, mempengaruhi atau membujuk, dan mengingatkan pasar sasaran atas perusahaan dan produknya agar bersedia menerima, membeli, dan loyal pada produk yang ditawarkan perusahaan yang bersangkutan (Tjiptono \& Chandra, 2011).

\section{METODE PENELITIAN}

Penelitian ini menggunakan metode kualitatif yang terdiri dari beberapa kegiatan penelitian yaitu observasi (pengamatan), interview (wawancara), kuesioner (angket) dan gabungan ketiganya. Populasi dalam penelitian ini adalah semua orang yang menggunakan produk Pasta Gigi Pepsodent di Perumahan Ciledug Indah 2. Teknik pengambilan sampel yang digunakan dalam penelitian ini adalah probability sampling, yaitu "teknik pengambilan sampel yang memberikan peluang yang sama bagi setiap unsur (anggota) populasi untuk dipilih menjadi anggota sampel." Jumlah sampel dalam penelitian adalah sebanyak 67 responden yang merupakan konsumen Pepsodent di Perumahan Ciledug Indah 2. Dalam penelitian ini dilakukan pengujian instrumen penelitian yaitu dengan uji validitas, uji reliabilitas, uji normalitas, uji multikolinieritas, uji heteroskedastisitas. Analisis data dalam penelitian ini yaitu dengan korelasi sederhana dan analisis regresi linier. 


\section{HASIL DAN PEMBAHASAN}

\section{Analisis Korelasi Sederhana}

Hasil analisis korelasi sederhana dapat dilihat pada tabel Correlations dari output SPSS. Penentuan seberapa erat hubungan antara variabel independen dan variabel dependen dilakukan dengan melihat nilai Correlation Coefficient untuk setiap hubungan, baik pada Kendall's tau-b maupun Spearman. Nilai korelasi mendekati 1 atau -1 berarti hubungan antar variabel adalah erat. Sebaliknya, jika nilai korelasi mendekati 0, maka dapat dikatakan bahwa hubungan antar variabel tidak erat. Penentuan keeratan hubungan antara variabel independen dan variabel dependen juga bisa dilakukan dengan melihat nilai Sig.(2-tailed). Jika nilai tersebut lebih besar dari tingkat kesalahan yang digunakan, maka Ho diterima. Sebaliknya, jika nilai tersebut lebih kecil dari tingkat kesalahan yang digunakan, maka Ho ditolak, dan Ha diterima. Ho adalah hipotesis yang menyatakan bahwa tidak ada hubungan antara variabel independen dan variabel dependen. Ha adalah hipotesis yang menyatakan bahwa ada hubungan antara variabel independen dan variabel dependen. Penentuan dengan cara demikian biasa disebut uji signifikansi (Duwi Priyatno, 2014).

Tabel 1

Hasil Analisis Korelasi Sederhana

\begin{tabular}{|c|c|c|c|c|c|c|}
\hline \multicolumn{7}{|c|}{ Correlations } \\
\hline & & & Citra Merek & $\begin{array}{c}\text { Kualitas } \\
\text { Produk } \\
\end{array}$ & Promosi & $\begin{array}{l}\text { Keputusan } \\
\text { Pembelian }\end{array}$ \\
\hline \multirow{12}{*}{ Kendall's tau_b } & \multirow[t]{3}{*}{ Citra Merek } & Correlation Coefficient & 1.000 & $631^{\prime \prime}$ & $.188^{\prime}$ & $.496 "$ \\
\hline & & Sig. (2-tailed) & & .000 & .047 & .000 \\
\hline & & $\mathrm{N}$ & 67 & 67 & 67 & 67 \\
\hline & \multirow{3}{*}{ Kualitas Produk } & Correlation Coefficient & $631^{\prime \prime}$ & 1.000 & $352^{\prime \prime}$ & $.530^{\mathrm{m}}$ \\
\hline & & Sig. (2-tailed) & .000 & & .000 & .000 \\
\hline & & $\mathrm{N}$ & 67 & 67 & 67 & 67 \\
\hline & \multirow[t]{3}{*}{ Promosi } & Correlation Coefficient & $188^{\circ}$ & $.352^{\prime \prime}$ & 1.000 & .169 \\
\hline & & Sig. (2-tailed) & .047 & .000 & & .073 \\
\hline & & $\mathrm{N}$ & 67 & 67 & 67 & 67 \\
\hline & \multirow{3}{*}{ Keputusan Pembelian } & Correlation Coefficient & $.496 "$ & $.530^{\prime \prime}$ & 169 & 1.000 \\
\hline & & Sig. (2-tailed) & .000 & .000 & .073 & \\
\hline & & N & 67 & 67 & 67 & 67 \\
\hline \multirow[t]{12}{*}{ Spearman's rho } & \multirow[t]{3}{*}{ Citra Merek } & Correlation Coefficient & 1.000 & $.738^{\prime \prime}$ & $.254^{\circ}$ & $.622^{\mathrm{m}}$ \\
\hline & & Sig. (2-tailed) & & .000 & .038 & .000 \\
\hline & & $\mathrm{N}$ & 67 & 67 & 67 & 67 \\
\hline & \multirow[t]{3}{*}{ Kualitas Produk } & Correlation Coefficient & $.738^{\prime \prime \prime}$ & 1.000 & $.447^{\prime \prime}$ & $.646^{\prime \prime \prime}$ \\
\hline & & Sig. (2-tailed) & .000 & & .000 & .000 \\
\hline & & $\mathrm{N}$ & 67 & 67 & 67 & 67 \\
\hline & \multirow[t]{3}{*}{ Promosi } & Correlation Coefficient & $254^{\circ}$ & $.447^{\prime \prime}$ & 1.000 & .212 \\
\hline & & Sig. (2-tailed) & .038 & .000 & & .086 \\
\hline & & $\mathrm{N}$ & 67 & 67 & 67 & 67 \\
\hline & \multirow[t]{3}{*}{ Keputusan Pembelian } & & $.6222^{\mathrm{m}}$ & $.646^{\mathrm{m}}$ & .212 & 1.000 \\
\hline & & Sig. (2-tailed) & .000 & .000 & .086 & \\
\hline & & $\mathrm{N}$ & 67 & 67 & 67 & 67 \\
\hline
\end{tabular}

\section{Analisis Korelasi Variabel Citra Merek dan Variabel Keputusan Pembelian}

Untuk analisis menggunakan pendekatan Kendall's tau-b, nilai Correlation Coefficient variabel citra merek dan variabel keputusan pembelian adalah 0,496; mendekati angka 0 . Berdasarkan hasil tersebut dapat dikatakan bahwa hubungan variabel citra merek dan variabel keputusan pembelian kurang erat. Untuk analisis menggunakan pendekatan Spearman's rho, nilai Correlation Coefficient variabel citra merek dan variabel keputusan pembelian adalah 0,622; mendekati angka 1. Berdasarkan hasil tersebut dapat dikatakan bahwa hubungan variabel citra merek dan variabel keputusan pembelian cukup erat.

Ho: Tidak terdapat pengaruh signifikan antara citra merek terhadap keputusan masyarakat menggunakan pasta gigi pepsodent.

H1: Terdapat pengaruh signifikan antara citra merek terhadap keputusan masyarakat menggunakan pasta gigi pepsodent.

Pada tabel 1 terlihat bahwa nilai Sig. (2-tailed) untuk hubungan variabel citra merek dan variabel keputusan pembelian, baik menggunakan pendekatan Kendall's tau-b maupun Spearman's rho, adalah 0,00. Nilai tersebut lebih kecil dari tingkat kesalahan yang digunakan, yaitu $0,1(10 \%)$. Berdasarkan hasil tersebut, dapat disimpulkan bahwa Ho ditolak dan H1 diterima, terdapat pengaruh signifikan antara citra merek terhadap keputusan masyarakat menggunakan pasta gigi pepsodent. 
Analisis Korelasi Variabel Kualitas Produk dan Variabel Keputusan Pembelian

Untuk analisis menggunakan pendekatan Kendall's tau-b, nilai Correlation Coefficient variabel kualitas produk dan variabel keputusan pembelian adalah 0,530; mendekati angka 1 . Berdasarkan hasil tersebut dapat dikatakan bahwa hubungan variabel kualitas produk dan variabel keputusan pembelian cukup erat. Untuk analisis menggunakan pendekatan Spearman's rho, nilai Correlation Coefficient variabel kualitas produk dan variabel keputusan pembelian adalah 0,646; mendekati angka 1. Berdasarkan hasil tersebut dapat dikatakan bahwa hubungan variabel kualitas produk dan variabel keputusan pembelian cukup erat.

Ho: Tidak terdapat pengaruh signifikan antara kualitas produk terhadap keputusan masyarakat menggunakan pasta gigi pepsodent.

H1: Terdapat pengaruh signifikan antara kualitas produk terhadap keputusan masyarakat menggunakan pasta gigi pepsodent.

Pada tabel 1 terlihat bahwa nilai Sig. (2-tailed) untuk hubungan variabel kualitas produk dan variabel keputusan pembelian, baik menggunakan pendekatan Kendall's tau-b maupun Spearman's rho, adalah 0,00. Nilai tersebut lebih kecil dari tingkat kesalahan yang digunakan, yaitu $0,1(10 \%)$. Berdasarkan hasil tersebut, dapat disimpulkan bahwa Ho ditolak dan H1 diterima, terdapat pengaruh signifikan antara kualitas produk terhadap keputusan masyarakat menggunakan pasta gigi pepsodent.

\section{Analisis Korelasi Variabel Bauran Promosi dan Variabel Keputusan Pembelian}

Untuk analisis menggunakan pendekatan Kendall's tau-b, nilai Correlation Coefficient variabel bauran promosi dan variabel keputusan pembelian adalah 0,169; mendekati angka 0 . Berdasarkan hasil tersebut dapat dikatakan bahwa hubungan variabel promosi dan variabel keputusan pembelian kurang erat. Untuk analisis menggunakan pendekatan Spearman's rho, nilai Correlation Coefficient variabel promosi dan variabel keputusan pembelian adalah 0,212; mendekati angka 0. Berdasarkan hasil tersebut dapat dikatakan bahwa hubungan variabel promosi dan variabel keputusan pembelian cukup erat.

Ho: Tidak terdapat pengaruh signifikan antara bauran promosi terhadap keputusan masyarakat menggunakan pasta gigi pepsodent.

H1: Terdapat pengaruh signifikan antara bauran promosi terhadap keputusan masyarakat menggunakan pasta gigi pepsodent.

Pada tabel 1 terlihat bahwa nilai Sig. (2-tailed) untuk hubungan variabel promosi dan variabel keputusan pembelian, baik menggunakan pendekatan Kendall's tau-b maupun Spearman's rho, adalah 0,00. Nilai tersebut lebih kecil dari tingkat kesalahan yang digunakan, yaitu 0,1 (10\%). Berdasarkan hasil tersebut, dapat disimpulkan bahwa Ho ditolak dan H1 diterima, terdapat pengaruh signifikan antara bauran promosi terhadap keputusan masyarakat menggunakan pasta gigi pepsodent.

\section{Analisis Regresi Linier Berganda}

Tabel 2

Hasil Analisis Regresi Linier Berganda - Coefficientsa - Metode Enter

Coefficients $^{\mathrm{a}}$

\begin{tabular}{|c|c|c|c|c|c|c|}
\hline \multirow[b]{2}{*}{ Mod } & & \multicolumn{2}{|c|}{ Unstandardized Coefficients } & \multirow{2}{*}{$\begin{array}{c}\text { Standardized } \\
\text { Coefficients } \\
\text { Beta } \\
\end{array}$} & \multirow[b]{2}{*}{$\mathrm{t}$} & \multirow[b]{2}{*}{ Sig. } \\
\hline & & B & Std. Error & & & \\
\hline \multirow[t]{4}{*}{1} & (Constant) & 3.251 & 1.986 & & 1.637 & .107 \\
\hline & Citra Merek & .264 & .140 & .264 & 1.887 & .064 \\
\hline & Kualitas Produk & .482 & .152 & .479 & 3.174 & .002 \\
\hline & Promosi & .026 & .101 & .026 & .256 & .799 \\
\hline
\end{tabular}

a. Dependent Variable: Keputusan Pembelian

Sumber: Output SPSS

Pada tabel terlihat bahwa variabel promosi memiliki nilai Sig. lebih besar dari tingkat kesalahan yang digunakan $(0,799>0,1)$. Berdasarkan kenyataan tersebut, variabel promosi dikatakan tidak memiliki pengaruh yang signifikan terhadap variabel keputusan pembelian, dan tidak akan digunakan dalam tahapan analisis regresi linier berganda yang selanjutnya. 
Untuk memudahkan hal tersebut, analisis regresi linier berganda akan dilanjutkan dengan metode backward. Menurut Priyatno (2014), pada analisis regresi linier dengan metode backward semua variabel mula-mula dimasukkan ke dalam model regresi, kemudian variabel yang tidak layak akan dikeluarkan satu per satu.

Setelah menerapkan langkah-langkah tersebut, maka hasil Output SPSS yang muncul akan terdiri dari Model. Model pertama adalah hasil analisis regresi linier berganda dengan metode enter, sedangkan yang kedua adalah hasilnya dengan metode backward.

\section{Tabel 3}

\section{Hasil Analisis Regresi Linier Berganda - Model Summary}

\begin{tabular}{|l|l|r|r|r|}
\hline \multicolumn{6}{|c|}{ Model Summary } \\
\hline Model & R & R Square & $\begin{array}{c}\text { Adjusted R } \\
\text { Square }\end{array}$ & $\begin{array}{c}\text { Std. Error of } \\
\text { the Estimate }\end{array}$ \\
\hline 1 &, $715^{\text {a }}$ &, 511 &, 488 &, 71349 \\
2 &, $715^{\mathrm{b}}$ &, 511 &, 495 &, 70826 \\
\hline
\end{tabular}

\section{Sumber: Output SPSS}

Nilai R adalah korelasi berganda, yaitu korelasi antara dua atau lebih variabel independen terhadap variabel dependen. Nilai $R$ berkisar antara 0 sampai 1 . Jika mendekati 1 maka hubungan makin erat, tetapi jika mendekati 0 maka hubungan makin lemah. Pada Tabel terlihat bahwa nilai $\mathrm{R}$ sebesar 0,715; mendekati angka 1, sehingga dapat dikatakan bahwa hubungan antara variabel citra merek dan kualitas produk dengan variabel keputusan pembelian cukup erat.

R Square (R2), atau kuadrat dari R, menunjukkan koefisien determinasi. Angka ini akan diubah ke bentuk persen, yang artinya persentase sumbangan pengaruh variabel-variabel independen terhadap variabel dependen. Adjusted R Square adalah R Square yang telah disesuaikan. Nilai ini juga menggambarkan besarnya sumbangan pengaruh variabel-variabel independen terhadap variabel dependen. Bedanya, Adjusted R Square biasanya digunakan untuk mengukur sumbangan pengaruh jika dalam regresi menggunakan lebih dari dua variabel independen. Pada tabel 3 terlihat bahwa nilai Adjusted R Square adalah 0,495. Hal tersebut dapat diartikan variabel citra merek dan kualitas produk memiliki sumbangan pengaruh terhadap variabel keputusan pembelian sebesar 49,5\%; sedangkan sisanya 50,5\% adalah sumbangan pengaruh variabel lain yang tidak diikutsertakan dalam penelitian. Std. (Standard) Error of the Estimate adalah ukuran kesalahan prediksi. Pada Tabel nilai standard error of the estimate sebesar 0,70826; artinya kesalahan yang dapat terjadi dalam memprediksi variabel keputusan pembelian menggunakan variabel citra merek dan kualitas produk sebesar 70,83\%.

\section{Tabel 4}

Hasil Analisis Regresi Linier Berganda - Coefficientsa - Metode Backward

Coefficients $^{a}$

\begin{tabular}{|c|c|c|c|c|c|c|}
\hline \multirow[b]{2}{*}{ Mod } & & \multicolumn{2}{|c|}{ Unstandardized Coefficients } & \multirow{2}{*}{$\begin{array}{c}\text { Standardized } \\
\text { Coefficients } \\
\text { Beta } \\
\end{array}$} & \multirow[b]{2}{*}{$\mathrm{t}$} & \multirow[b]{2}{*}{ Sig. } \\
\hline & & $B$ & Std. Error & & & \\
\hline \multirow[t]{4}{*}{1} & (Constant) & 3,251 & 1,986 & & 1,637 & ,107 \\
\hline & Citra Merek & ,264 & 140 & ,264 & 1,887 & ,064 \\
\hline & Kualitas Produk & ,482 & ,152 & .479 & 3,174 &, 002 \\
\hline & Promosi & ,026 & 101 &, 026 & ,256 &, 799 \\
\hline \multirow[t]{3}{*}{2} & (Constant) & 3,548 & 1,598 & & 2,220 &, 030 \\
\hline & Citra Merek & ,260 & 138 & , 260 & 1,884 & .064 \\
\hline & Kualitas Produk & 497 & 139 & 495 & 3,587 & ,001 \\
\hline
\end{tabular}

Sumber: Output SPSS

Unstandardized Coefficients adalah nilai koefisien yang tidak terstandarisasi atau tidak memiliki acuan, nilai ini menggunakan satuan yang digunakan pada data variabel dependen. Koefisien B terdiri dari nilai (Constant), yaitu nilai variabel dependen jika semua variabel independen bernilai 0 , dan koefisien regresi, yaitu nilai yang menunjukkan penurunan atau 
peningkatan nilai variabel dependen berdasarkan nilai variabel-variabel independen. Nilai-nilai inilah yang masuk ke dalam persamaan regresi linier berganda. Berdasarkan Tabel 4, maka koefisien regresi yang terbentuk adalah sebagai berikut:

$$
\mathrm{Y}=3,548+0,26(\mathrm{X} 1)+0,497(\mathrm{X} 2)
$$

Keterangan:

a. Jika variabel citra merek dan kualitas produk bernilai 0 , maka keputusan pembelian (Y) adalah 3,548.

b. Untuk setiap unit perubahan X1 (citra merek) maka nilai keputusan pembelian akan ikut berubah sebesar 0,26.

c. Untuk setiap unit perubahan nilai X2 (kualitas produk) maka nilai keputusan pembelian akan ikut berubah sebesar 0,497.

\section{Uji t Variabel Citra Merek (X1)} berikut:

Hipotesis pengaruh variabel Citra Merek terhadap keputusan pembelian adalah sebagai

Ho: Tidak terdapat pengaruh signifikan antara Citra Merek terhadap keputusan masyarakat menggunakan pasta gigi pepsodent.

H1: Terdapat pengaruh signifikan antara Citra Merek terhadap keputusan masyarakat menggunakan pasta gigi pepsodent.

Pada tabel 4 terdapat nilai t hitung untuk Citra Merek sebesar 1,887. $\mathrm{t}$ tabel dicari dengan tingkat kesalahan 0,1 (10\%) dan df $=63$ (jumlah data-jumlah variabel independen-1). Dengan ketentuan tersebut, $t$ tabel yang didapat adalah 1,669. Nilai Sig. untuk variabel Citra Merek adalah 0,064. Karena nilai t hitung 1,887 lebih besar dari nilai t tabel 1,669; serta nilai Sig. 0,064 lebih kecil dari tingkat kesalahan 0,1; maka Ho ditolak dan H1 diterima, terdapat pengaruh signifikan antara Citra Merek terhadap keputusan masyarakat menggunakan pasta gigi pepsodent.

\section{Uji t Variabel Kualitas Produk (X2)}

Hipotesis pengaruh variabel Kualitas Produk terhadap keputusan pembelian adalah sebagai berikut:

Ho: Tidak terdapat pengaruh signifikan antara Kualitas Produk terhadap keputusan masyarakat menggunakan pasta gigi pepsodent.

H1: Terdapat pengaruh signifikan antara Kualitas Produk terhadap keputusan masyarakat menggunakan pasta gigi pepsodent.

Pada tabel 4 terdapat nilai t hitung untuk Kualitas Produk sebesar 3,174. t tabel dicari dengan tingkat kesalahan $0,1(10 \%)$ dan $\mathrm{df}=63$ (jumlah data-jumlah variabel independen-1). Dengan ketentuan tersebut, $t$ tabel yang didapat adalah 1,669. Nilai Sig. untuk variabel Kualitas Produk adalah 0,002. Karena nilai t hitung 3,174 lebih besar dari nilai t tabel 1,669; serta nilai Sig. 0,002 lebih kecil dari tingkat kesalahan 0,1; maka Ho ditolak dan H1 diterima, terdapat pengaruh signifikan antara Kualitas Produk terhadap keputusan masyarakat menggunakan pasta gigi pepsodent.

\section{Uji t Variabel Bauran Promosi (X3)}

Hipotesis pengaruh variabel bauran promosi terhadap keputusan pembelian adalah sebagai berikut:

Ho: Tidak terdapat pengaruh signifikan antara bauran promosi terhadap keputusan masyarakat menggunakan pasta gigi pepsodent.

H1: Terdapat pengaruh signifikan antara bauran promosi terhadap keputusan masyarakat menggunakan pasta gigi pepsodent.

Pada tabel 4 terdapat nilai t hitung untuk variabel bauran promosi sebesar 0,256. $t$ tabel dicari dengan tingkat kesalahan $0,1(10 \%)$ dan $\mathrm{df}=63$ (jumlah data-jumlah variabel independen-1). Dengan ketentuan tersebut, $t$ tabel yang didapat adalah 1,669. Nilai Sig. untuk variabel promosi adalah 0,799. Karena nilai $-1,669<0,256<1,669$; serta nilai sig. 0,799 lebih 
besar dari tingkat kesalahan 0,1 ; maka $\mathrm{H} 0$ diterima, tidak terdapat pengaruh signifikan antara promosi terhadap keputusan masyarakat menggunakan pasta gigi pepsodent.

Uji F

Tabel 5

Hasil Analisis Regresi Linier Berganda - ANOVA ${ }^{\mathrm{a}}$

ANOVA $^{\text {a }}$

\begin{tabular}{|c|c|c|c|c|c|c|}
\hline \multicolumn{2}{|c|}{ Model } & $\begin{array}{l}\text { Sum of } \\
\text { Squares }\end{array}$ & df & Mean Square & $\mathrm{F}$ & Sig. \\
\hline \multirow[t]{3}{*}{1} & Regression & 33,534 & 3 & \multirow{3}{*}{$\begin{array}{r}11,509 \\
, 509\end{array}$} & \multirow[t]{3}{*}{21,958} & \multirow[t]{3}{*}{$.000^{\mathrm{b}}$} \\
\hline & Residual & 32,071 & 63 & & & \\
\hline & Total & 65,605 & 66 & & & \\
\hline \multirow[t]{3}{*}{2} & Regression & 33,500 & 2 & 16,750 & \multirow[t]{3}{*}{33,392} & \multirow[t]{3}{*}{, $000^{\circ}$} \\
\hline & Residual & 32,104 & 64 & \multirow[t]{2}{*}{, 502} & & \\
\hline & Total & 65,605 & 66 & & & \\
\hline
\end{tabular}

Berikut adalah hipotesis pengaruh variabel citra merek dan kualitas produk terhadap keputusan pembelian:

Ho: Tidak terdapat pengaruh signifikan antara citra merek dan kualitas produk terhadap keputusan masyarakat menggunakan pasta gigi pepsodent.

H1: Terdapat pengaruh signifikan antara citra merek dan kualitas produk terhadap keputusan masyarakat menggunakan pasta gigi pepsodent.

Pada tabel 5 terdapat nilai $\mathrm{F}$ hitung hitung sebesar 33,392. F tabel dicari dengan tingkat kesalahan $0,1(10 \%)$, df $1=3$ (jumlah variabel-1), dan df $2=63$ (jumlah data- jumlah variabel independen-1). Dengan ketentuan tersebut, F tabel yang didapat adalah 2,17. Nilai Sig. yang didapat adalah 0,000. Karena nilai $F$ hitung 33,392 lebih besar dari nilai $F$ tabel 2,17; serta nilai Sig. 0,000 lebih kecil dari tingkat kesalahan 0,1; maka Ho ditolak dan H1 diterima, terdapat pengaruh signifikan antara citra merek dan kualitas produk terhadap keputusan masyarakat menggunakan pasta gigi pepsodent.

\section{Interpretasi Hasil Penelitian}

Dari hasil interpretasi nilai variabel-variabel yang diikutsertakan dalam penelitian ini, dapat dikatakan bahwa secara keseluruhan citra merek, kualitas produk, dan promosi pasta gigi pepsodent menurut para responden cukup baik. Dari sekian banyak hasil interpretasi nilai ratarata jawaban responden Setuju. Yang mendapat hasil terburuk adalah variabel kualitas produk, karena mendapat total nilai rata-rata 3,80. Yang memperoleh hasil terbaik adalah variabel bauran promosi, karena mendapat total nilai rata-rata 3,93. Variabel keputusan pembelian juga memiliki hasil interpretasi nilai rata-rata jawaban responden Setuju dan mendapat total nilai rata-rata 3,81. Kenyataan tersebut juga menggambarkan besarnya minat responden untuk menggunakan pasta gigi pepsodent.

Pada bagian pembahasan analisis korelasi sederhana antara variabel-variabel independen dengan variabel dependen, telah dijelaskan bahwa hubungan variabel- variabel tersebut dengan variabel dependen cukup kuat. Nilai koefisien korelasi untuk masing-masing hubungan variabel independen dengan variabel dependen yang mendekati 0 dan mendekati 1 seimbang. Hasil tersebut berlaku baik untuk koefisien korelasi yang diperoleh dengan pendekatan Kendall ${ }^{\text {ee }}$ tau-b maupun Spearman ${ }^{\text {ee }}$ s rho. variabel kualitas jasa, harga, dan citra merek masingmasing secara parsial memiliki hubungan dengan variabel keputusan pembelian. Hal tersebut disimpulkan berdasarkan nilai Sig. (2-tailed) untuk setiap hubungan antara variabel independen dan variabel dependen yang lebih kecil dari tingkat kesalahan yang digunakan dalam penelitian.

Hasil analisis regresi linier berganda tidak jauh berbeda dengan hasil analisis korelasi sederhana. Karena hubungan antara masing-masing variabel independen dengan variabel dependen tergolong lemah, maka sumbangan pengaruh variabel-variabel independen terhadap variabel dependen juga tidak cukup besar, yaitu hanya 49,5\%. Hasil uji t untuk setiap variabel independen, menunjukkan bahwa variabel citra merek dan kualitas produk memiliki pengaruh 
yang cukup signifikan terhadap variabel keputusan pembelian. Di sisi lain, variabel promosi tidak memiliki pengaruh yang cukup signifikan terhadap variabel keputusan pembelian. Hasil uji F menunjukkan bahwa secara simultan/bersama-sama, variabel citra merek dan kualitas produk memiliki pengaruh yang cukup signifikan terhadap variabel keputusan pembelian. Variabel promosi tidak diikutsertakan dalam uji $\mathrm{F}$ karena variabel tersebut tidak memiliki pengaruh yang cukup signifikan terhadap keputusan pembelian, sehingga dapat dikatakan tidak layak untuk diikutsertakan dalam uji tersebut.

\section{KESIMPULAN}

Dari hasil penelitian ini dapat diambil beberapa kesimpulan antara lain: 1) hasil pengujian dengan spss variabel Citra Merek secara parsial memiliki pengaruh signifikan terhadap minat masyarakat untuk menggunakan pasta gigi pepsodent, 2) hasil pengujian dengan spss variabel Kualitas Produk secara parsial memiliki pengaruh signifikan terhadap minat masyarakat untuk menggunakan pasta gigi pepsodent, 3) hasil pengujian dengan spss variabel Bauran Promosi secara parsial tidak memiliki pengaruh signifikan terhadap minat masyarakat untuk menggunakan pasta gigi pepsodent, 4) Variabel Citra Merek dan Kualitas Produk secara simultan memiliki pengaruh signifikan terhadap minat masyarakat untuk menggunakan pasta gigi pepsodent.

\section{DAFTAR PUSTAKA}

Allenby, G. M., \& Rossi, P. E. (1991). Quality perceptions and asymmetric switching between brands. Marketing science, 10(3), 185-204.

Athiyaman, A. (1997). Linking student satisfaction and service quality perceptions: the case of university education. European journal of marketing, 31(7), 528-540.

Cravens, D. W., \& Piercy, N. (2006). Strategic Marketing (Vol. 7). New York: McGraw-Hill.

Grunert, K. G. (2005). Food quality and safety: consumer perception and demand. European review of agricultural economics, 32(3), 369-391

Jain, S. C., \& Haley, G. T. (2009). Marketing Planning and Strategy. Cincinnati South-Western Publishing Company 1985.

Kotler, P. \& Keller, K.K. (2010). Manajemen Pemasaran (Edisi 13). Jakarta: Erlangga

Priyatno, D. (2014). Analisis Korelasi, Regresi, dan Multivariate dengan SPSS. Yogyakarta: PENERBIT GAVA MEDIA

Priyatno, D. (2014). SPSS 22 Pengolah Data Terpraktis. Yogyakarta: CV. ANDI

Rust, R. T., Katherine, L. N., \& Zeithaml, V. A. (2004). Return on marketing: Using customer equity to focus marketing strategy. Journal of Marketing, 68(1), 109-127.

Steenkamp, J. B. E., Batra, R., \& Alden, D. L. (2003). How perceived brand globalness creates brand value. Journal of International Business Studies, 34(1), 53-65.

Tjiptono, F \& Chandra, G. (2011). Service, Quality \& Satisfaction (Edisi 3). Yogyakarta: CV. ANDI

Tjiptono, F \& Chandra, G. (2012). Pemasaran Strategik (Edisi 2). Yogyakarta: CV. ANDI.

Völckner, F., Sattler, H., Hennig-Thurau, T., \& Ringle, C. M. (2010). The role of parent brand quality for service brand extension success. Journal of Service Research, 13(4), 379-396. 